\title{
The Effect of Application of REACT Learning Strategies on Mathematics Learning Achievements: Empirical Analysis on Learning Styles of Junior High School Students
}

\author{
Matin Enggar Putri ${ }^{1}$, Mardiyana ${ }^{2}$, Dewi Retno Sari Saputro ${ }^{3}$
}

\begin{tabular}{l} 
ARTICLE INFO \\
\hline Article History: \\
Received 02.10.2018 \\
Received in revised form \\
24.01 .2019 \\
Accepted \\
Available online 01.04 .2019
\end{tabular}

Available online 01.04.2019

\begin{abstract}
This study aims to determine the effect of REACT learning strategies on mathematics learning achievement in terms of the learning sty les of eighth grade students of public junior high schools in Sragen district. This study was a quasi-experimental study with a $2 \times 3$ factorial design. The population of this study was eighth grade students of the public junior high schools in Sragen Regency in the 2015/2016 academic year. The sample was taken by stratified cluster random sampling. The instrument used to collect data is by distributing questionnaire to test the mathematics learning achievement and student learning style. Data analy sis techniques use two -way variance analysis with unequal cells. The results show that REACT learning strategies produce mathematics learning achievements that are better than direct learning in material relations and functions. Moreover, mathematics learning achievement of students who have a visual learning sty le as well as students with auditory learning styles, students with visual learning styles have better learning achievement than students with kinesthetic learning styles, while students with auditory learning styles have the same achievement with those with kinesthetic learning styles. In addition, in the category of visual, auditory, and kinesthetic learning styles, students who were treated with REACT learning strategies had better mathematics learning achievement than students who were treated with direct learning. Lastly, in each REACT learning and direct learning, students with visual learning styles have mathematics learning achievements that are as good as students who have auditory learning styles. Students with visual learning styles have better mathematics learning achievement than students with kinesthetic learning styles, while students with auditory learning styles have mathematics learning achievements that are as good as students who have kinesthetic learning styles.
\end{abstract}

(C) IJERE. All rights reserved

Keywords:

REACT Learning, Direct Learning, learning achievement, learning style

\section{INTRODUCTION}

Education that is able to support future development is education that is able to develop the potential of students, so that the concerned person must be able to apply what is learned in school to face the problems faced in daily life today and in the future (Dawe et al., 2005). One field of study that has an important role in the world of education and in dealing with problems of daily life is mathematics (Mason \& Spence, 1999). Although not all of these problems include mathematical problems, mathematics has an important role in answering everyday problems. In accordance with the opinion expressed by Skemp (1971, 132) that " mathematics is also a valuable and general technique for satisfying other needs. It is an essential tool for science, technology, and commerce; and for entry to many professions".

Therefore mathematics is a subject given to all levels starting from elementary school to equip students with the ability to think logically, analytically, systematically, and creatively and have the ability to cooperate (Stein et al., 1996; Mulyanto et al., 2018; Saputra et al., 2018). This is because mathematics is one of the most fundamental sources of knowledge. In other words, many of the sciences whose discovery and development depend on mathematics, so that mathematics subjects are very beneficial for students as a basic science for application in other fields. The importance of the role of mathematics in life is not supported by the reality that occurs (Bharadwaj et al., 2012). Especially in Indonesia, junior high school students' mathematics learning achievements are still relatively low. The low level of mathematics learning achievement was also experienced by students of public junior high school in Sragen Regency. The data show s that the low est value of the mathematics final examination is 15.0 and the highest value is $100.0 \mathrm{while}$ the average score of students is 48.35 is still low compared to the national level national average (56.60). This

\footnotetext{
${ }^{1}$ Corresponding e-mail: matin.enggar@gmail.com; orcid.org/0000-0001-9803-2913

2 orcid.org/0000-0002-8329-5355

3 orcid.org/0000-0002-6999-6120

1,2,3, Postgraduate Program, Universitas Sebelas Maret, Surakarta 57126, Indonesia
} 
indicates that the mathematics learning achievement of students in the public junior high schools in Sragen Regency is still low. Thus an effort is needed to improve the quality of mathematics learning in order to improve students' mathematics learning achiev ements, especially in Sragen district. According to the theory of learning styles, each student learns in different ways (Bostrom, 2011: 18). Therefore, student learning achievements that can be caused by learning strategies used by teachers are sometimes not in accordance with student learning styles. Here, research needs to be done to learn the best learning for mathematics learning achievement in in material relations and functions.

\section{LITERATURE REVIEW}

\section{Learning Achievement and Learning Strategies}

According to Kasirye $(2009,12)$ learning achievement is defined as:

"a result of the combination of various inputs. Learning achievement is hypothesized to depend on: children's characteristics such as age, innate ability, and health status; family background such as parent education and parental preferences for the child education; and school inputs including teachers, textbooks, desks, and tables".

The statement implies that learning achievement is the result of a combination of various activities and learning processes that are accepted by students which are manifested in an action. Real action results in a change tow ards a better one. This make that some socio-economic as well as educational considerations of child characteristics such as age, innate abilities, and health status, parental education backgrounds and parents' preferences for children's education, and school inputs including teachers, textbooks, tables, and tables are likely to affect student learning achievement:.

Brown \& McNamara $(2005,16)$ define mathematics learning achievement as follows

"Mathematical achievement is understood more in terms of performance than prescribed mathematical procedures. This is quantifiable through diagnostic testing, and broad understanding is anchored around statistically defined environment test indicators. The meaning of the statement is that mathematical achievement is understood more in terms of the performance of the specified mathematical procedures. This is measured through diagnostic tests, and broader understanding begins with test indicators in statistics that are defined by the environment."

Based on the opinion of Brown \& McNamara ((2005), the measurement of mathematics learning achievement can be done through tests made based on indicators that are in accordance with the abilities measured.

Low absorption capacity can be triggered by a lack of meaningful learning experiences. This might be because learning experiences might rely more textually on textbooks, emphasizing to memorize formulas without knowing where the formula came from or how to construct the formula (Schoenfeld, 2009). In addition, the usefulness of the learning process may also not be conveyed so that the learning experience becomes meaningless. To overcome the need to change the paradigm of learning strategies used, namely from direct learning to innovative learning (Wood \& Ashfield, 2008). One of the causes of students 'low mathematics learning achievement is also influenced by a lack of students' understanding of the concepts contained in mathematics and it is still difficult for students to communicate mathematically (Hill et al., 2005; Henningsen \& Stein, 1997). The different learning influences the style characteristics of students. In addition, there are still many teachers who are fixated on a learning strategy that is used in the teaching and learning process continuously without ever modifying it or replacing it with another strategy even though the learning objectives to be achieved are different (Hill et al., 2005; Risw anto, 2016). Such learning can result in unoptimal achievement of learning objectives by students. Therefore, to realize the learning objectives, in the implementation of teaching and learning activities, teachers should pay attention to student learning styles and learning strategies so that learning achievement becomes optimal.

\section{REACT Learning Strategy}

One of the learning strategies that are expected to be able to optimize mathematics learning achievement and student learning style is the REACT learning strategy. The teacher must try to get students 
to find out for themselves or understand the concepts given, cooperate, and can apply the knowledge acquired to real life. This is a feature of learning that applies REACT learning strategies (Crow ford, 2001). REACT is an acronym of Relating, Experiencing, Applying, Cooperating, Transferring.

Relating is learning by linking the material being studied with the context of real life experience or prior know ledge. Experiencing is learning that makes students learn by doing mathematical activities (doing math) through exploration, discovery and search. Various experiences in the classroom can include manipulative use, problem solving activities, and laboratories. Applying is learning by applying learned concepts to be used, by providing realistic and relevant exercises. Cooperating is learning by conditioning students to w ork together, share, respond and communicate with other learners. Transferring is learning that encourages students to learn to use the knowledge they have learned into new contexts or situations that have not been learned in the classroom based on understanding (Arifin et al., 2014; Sapto et al., 2015).

REACT strategies have been implemented by Yuniawatika (2011) and Rohati (2011) whose research results show a positive impact of using REACT strategies in mathematics learning. REACT's strategy in the learning process is student-centered so that students are motivated to learn and understand the materials in mathematics, with motivated students being expected to optimize student learning activities so that later it will have an impact on optimal mathematics learning outcomes. Likewise, the results of Fauziah (2010) 's study which states that students who get learning through REACT strategies experience better learning outcomes than students who get direct learning, so the REACT strategy contributes significantly and is better than direct learning on understanding and solving math problem for junior high school students.

\section{Hypotheses}

Based on the explanation previously described, the purpose of this study is to find out the extent to which learning strategies have better mathematics learning achievements between REACT learning strategies and learning in material relations and functions, and which ones have more mathematics learning achievements either between students who have a visual, auditory or kinesthetic learning style. In the category of visual, auditory, and kinesthetic learning styles, which results in better learning achievement, students who are treated with REACT learning strategies or who have direct learning strategies. In each REACT learning and direct learning, which results in better learning achievement, students with visual, auditorial or kinesthetic learning styles. The benefits of this research are theoretically as reference material for consideration of further research and generate knowledge about REACT learning strategies to improve mathematics learning achievement. Practically, the results of this study are expected to provide innovation in the w orld of education, especially the implementation of the REACT strategy that is influenced by student learning styles. The results are expected as an alternative for teachers in overcoming the difficulties of students in mathematics learning, namely by choosing learning strategies used in the learning process in accordance with the learning styles of students so that mathematical concepts can be understood by students appropriately and effectively. Based on these descriptions, the hypotheses proposed in this study are as follows:

H_0A: There were no differences in mathematics learning achievement in students treated with the REACT learning approach and direct learning

H_0B: There are no differences in mathematics learning achievement betw een students with visual, auditory and kinesthetic learning styles

H_0AB: There is no interaction between learning approaches and student learning styles towards mathematics learning achievement.

\section{RESEARCH METHOD}

This research is a quasi-experimental study. The independent variables in this study is learning strategy, while the dependent variable is mathematics learning achievement. The learning strategies used are case-control examinations of learning with REACT learning style and direct learning style. The other independent variable that influences the dependent va riable is the learning style in the visual, auditory, and kinesthetic categories. The research design used in this study was a $2 \times 3$ factorial design. The population in this study were all eighth grade students of the public junior high schools in Sragen Regency in the odd 
semester of the 2015/2016 academic year while the samples in this study were eighth grade students in 3 public junior high schools in Sragen Regency namely Sragen 2 Public Junior High School, Gondang 2 Public Junior High School, and Sambirejo 2 Public Junior High School. There are taken 2 classes at each school. The sampling technique is by using stratified cluster random sampling technique.

The number of respondents was 190 students with details of 96 students as cases with REACT learning, and 94 as controls with direct learning. All students are Indonesian citizens, Javanese, and 14-16 years old. The methods used in this study are documentation methods, questionnaire methods and test methods. The data analysis technique used to test the hypothesis is a two-w ay analy sis of variance with unequal cells and a double comparison test with the Scheffe (1999) test (see also Draper \& Smith, 2014)..

\section{RESULTS}

The results of calculations with a two-way analysis of variance with unequal cells and a significance level of $5 \%$ are presented in Table 1, while summary of the variance analysis test is presented in Table 2.

Table 1. Description of Average Cells and Marginal Average

\begin{tabular}{lcccc}
\hline \multirow{2}{*}{ Learning } & \multicolumn{3}{c}{ Student learning style } & Marginal \\
\cline { 2 - 4 } & Visual & Auditorial & kinesthetic & Average \\
\hline REACT & 77.6190 & 75.8649 & 75.0588 & 75.7917 \\
Direct & 68.8000 & 68.0000 & 58.0000 & 67.6809 \\
Marginal Average & 73.3171 & 71.9351 & 66.5484 & \\
\hline
\end{tabular}

Table 2. Summary of Analysis of Two-Way Variances with Unequal Cells

\begin{tabular}{ccccccc}
\hline Source & $\mathrm{dK}$ & \multicolumn{1}{c}{$\mathrm{JK}$} & \multicolumn{1}{c}{$\mathrm{RK}$} & $F_{o b s}$ & $F_{t a b}$ & Verification \\
\hline $\mathrm{A}$ & 1 & 57863.655 & 57863.655 & 19.809 & 3.90 & $\mathrm{H}_{0}$ rejected \\
$\mathrm{B}$ & 2 & 14754.816 & 7377.408 & 4.656 & 3.045 & $\mathrm{H}_{0}$ rejected \\
$\mathrm{AB}$ & 2 & 2678.702 & 1339.351 & 0.805 & 3.045 & $\mathrm{H}_{0}$ accepted \\
Std. Error & 184 & 12886.998 & 70.038 & - & - & - \\
Total & 189 & 88184.171 & - & - & - & - \\
\hline
\end{tabular}

Based on Table 2, the results of the two-way variance analysis with unequal cells show a significant value of 0.05 . Thus, (1) H_0A is rejected. This means that there are differences in mathematics learning achievement in students treated with the REACT learning approach and conventional learning. Thus, (2) H_OB is rejected. This means that there are differences in mathematics learning achievement between students with visual, auditory and kinesthetic learning styles. Moreover, the statistical analysis shows that (3) $\mathrm{H}_{-} \mathrm{OAB}$ rejected. This means that there is an interaction between learning approaches and student learning styles towards mathematics learning achievement. The results of the average comparison test between lines can be presented in Table 3 .

From the results of the calculation, it $w$ as found that H_0A was rejected, so that there were differences in mathematics learning achievement in students treated with the REACT learning approach and direct learning. Because the learning variable only has a value of 2 (i.e. REACT and Direct), then the stimulation can be seen from the average. From the marginal mean, it show s that the average REACT learning strategy is greater than direct learning, so it can be concluded that students who are subjected to REACT lea rning strategies are better than direct learning. From the results of the ANOVA calculation, it is obtained that H0B is rejected. Therefore, it is necessary to do a mean comparative test between columns. A summary of the results of the average comparison test between columns is presented in Table 3.

Table 3. Summary of Mean Comparative Tests Between Columns

\begin{tabular}{lccc}
\hline $\mathrm{H}_{0}$ & $\mathrm{~F}_{\mathrm{obs}}$ & $2\left(\mathrm{~F}_{0,05 ; 2 ; 184}\right)$ & Results \\
\hline$\mu_{\cdot 1}=\mu_{\cdot 2}$ & 1,8081 & 6,09 & $\mathrm{H}_{0}$ is not rejected \\
$\mu_{\cdot 2}=\mu_{\cdot 3}$ & 10,6038 & 6,09 & $\mathrm{H}_{0}$ rejected \\
$\mu_{\cdot 1}=\mu_{\cdot 3}$ & 1,4782 & 6,09 & $\mathrm{H}_{0}$ is not rejected \\
\hline
\end{tabular}




\section{DISCUSSION}

Based on Table 3 and the marginal mean in Table 1, it can be concluded that students with visual learning styles have learning achievements that are as good as students with auditory learning styles, students with visual learning styles have better learning achievement than students with kinesthetic learning styles, while students with auditory learning styles have learning achievements that are as good as students with kinesthetic learning styles. The results of this study are in line with the results of a study conducted by Susanto (2016) which states that there are no significant differences in achievement between students with visual and auditory learning styles and auditorial and kinesthetic learning styles. Based on the results of the calculation of the two-cell variance analysis not the same on the interaction effect of $A B$ (learning strategy and student learning style) obtained $\mathrm{FAB}=0.805$ and $\mathrm{DK}=\{\mathrm{F} \mid \mathrm{F}>3.045\}$, this means $\mathrm{FAB} \notin \mathrm{DK}$. So that $\mathrm{H} 0 \mathrm{AB}$ is not rejected, meaning there is no interaction between learning strategies and learning styles on student learning achievement in material relations and functions. Thus, it is obtained (1) on REACT learning strategies and direct learning, students with visual learning styles have mathematical learning achiev ement that is equally good compared to students with auditory learning styles, students with visual learning styles have better mathematics learning achievement than students with style kinesthetic learning, while students with auditory learning styles have mathematics learning achievements that are equally good compared to students with kinesthetic learning styles. (2) In the category of visual, auditory and kinesthetic learning styles, REACT learning strategies produce mathematics learning achievements that are better than direct learning strategies

\section{CONCLUSION}

Regarding literacy, these findings highlight the visual aspects of the learning process. In addition, because the findings also reveal the need for efforts to improve the kinesthetic and auditory aspects of mathematics learning. In addition, this study successfully proved that the learning model with REACT can improve students' mathematics learning achievements. More specifically, the results show that students who were treated with REACT learning strategies produced better mathematics learning achievement than students whowere given direct learning in material relations and functions. Moreover, students with visual learning styles had Mathematics learning achievement is as good as students who have a uditory learning styles. Students with visual learning styles have better mathematics learning achievement than students with kinesthetic learning styles, while students with auditory learning styles have mathematics learning achievements that are as good as students who have kinesthetic learning styles. In the category of visual, auditory, and kinesthetic learning styles, students who were treated with REACT learning strategies had better mathematics learning achievement than students who were treated with direct learning. In each REACT learning and direct learning, students with visual learning styles have mathematics learning achievements that are as good as students who have auditory learning styles. Students with visual learning styles have better mathematics learning achievement than students with kinesthetic learning styles, while students with auditory learning styles have mathematics learning achievements that are as good as students who have kinesthetic learning styles.

The suggestions from the results of this study are for teachers that REACT learning strategies can be used as a reference in mathematics learning in the classroom, because based on the results of the research the strategy provides better learning achievement than direct learning. In addition, the teacher must also pay attention to other factors within the student, namely the student's learning style, because in this study student learning styles have an influence on student learning achievement.

The limitation of this study is to use case control studies based on cross sectional data. Thus, this test cannot predict in the long term the influence between the use of REACT learning strategies and student achievement. Further studies are expected to be able to examine the effect of REACT and mathematics learning achievements in longitudinal study designs. In addition, this study focuses on the influence of learning in the classroom context, which only considers teaching from teacher to student, and the learning strategies used. The implication is that students' socio-economic factors, and educational factors outside the class are not considered in this study. Future research is expected to involve factors outside the classroom in the relationship between the use of REACT learning models and student achievement. 
Putri ,M.E., Mardiyana \& Saputro,D.R.S. (2019). The effect of application of react learning strategies on mathematics learning achievements: Empirical analysis on learning styles of junior high school students. International Journal of Educational Research Review, 4(2), $231-237$.

\section{REFERENCES}

Arifin, A. T., Kartono, K., \& Sutarto, H. (2014). Keefektifan Strategi Pembelajaran React Pada Kemampuan Sisw Kelas VII Aspek Komunikasi Matematis. Kreano, Jurnal Matematika Kreatif-Inovatif, 5(1), 91-98.

Bharadwaj, P., De Giorgi, G., Hansen, D., \& Neilson, C. (2012). The gender gap in mathematics: Evidence from low-and middle-income countries (No. w18464). National Bureau of Economic Research.

Brown, T., \& McNamara, O. (2005). New teacher identity and regulative government the discursive formation of primary mathematics teacher education. New York: Springer Science Business Media, Inc.

Crawford, M. L. (2001). Teaching contextually: Research, rationale, and technique for improving student motivation and achievement in mathematics and science. Waco, Texas: CCI Publishing, Inc.

Dawe, G., Jucker, R., \& Martin, S. (2005). Sustainable development in higher education: current practice and future developments. A report to the Higher Education Academy, York (UK)(http://www. heacademy. ac. uk/assets/York/documents/ourwork/tla/sustainability/sustdevinHEfinal report. pdf).

Draper, N. R., \& Smith, H. (2014). Applied regression analysis(Vol. 326). John Wiley \& Sons.

Fauziah, A. (2010). Peningkatan Kemampuan Pemahaman dan Pemecahan Masalah Matematik Siswa SMP melalui Strategi REACT. Forum Kependidikan Jurnal Universitas Sriwijaya, 30 (1), 1 -13.

Henningsen, M., \& Stein, M. K. (1997). Mathematical tasks and student cognition: Classroom -based factors that support and inhibit high-level mathematical thinking and reasoning. Journal for research in mathematics education, 524-549.

Hill, H. C., Rowan, B., \& Ball, D. L. (2005). Effects of teachers' mathematical knowledge for teaching on student achievement. American educational research journal, 42(2), 371-406.

Kasirye, I. (2009). Determinants of learning achievement in Uganda. Economic Policy Research Centre, 12(01), 1131.

Mason, J., \& Spence, M. (1999). Beyond mere knowledge of mathematics: The importance of knowing-to act in the moment. In Forms of Mathematical Knowledge (pp. 135-161). Springer, Dordrecht.

Mulyanto, H., Gunarhadi, G., \& Indriayu, M. (2018). The effect of problem based learning model on student mathematics learning outcomes viewed from critical thinking skills. International Journal of Educational Research Review, 3(2), 37-45.

Risw anto, A. (2016). Pengaruh model pembelajaran kooperatif tipe team assisted individualization terhadap motivasi belajar mahasiswa. Mosharafa: Jurnal Pendidikan Matematika, 5(3), 293-304.

Rohati. (2011). Pengembangan Bahan Ajar Materi Bangun Ruang dengan Menggunakan Strategi Relating, Experiencing, Applying, Cooperating, Transferring (REACT) di Sekolang Menengah Pertama. Jurnal Edumatica Universitas Jambi, 01( 02), 61-73

Sapto, A. D., Suyitno, H., \& Susilo, B. E. (2015). Keefektifan Pembelajaran Strategi REACT dengan Model SSCS terhadap Kemampuan Komunikasi Matematika dan Percaya Diri Siswa Kelas VIII. Unnes Journal of Mathematics Education, 4(3).

Saputra, M. D., Joyoatmojo, S., \& Wardani, D. K. (2018). The assessment of critical-thinking-skill tests for accounting students of vocational high schools. International Journal of Educational Research Review, 3(4), 85-96.

Scheffé, H. (1999). The analysis of variance. New York: Wiley.

Schoenfeld, A. (2009). Learning to think mathematically: Problem solving, metacognition, and sense-making in mathematics. Colección Digital Eudoxus, (7).

Skemp, R. R. (1971). The psycholology of learning mathematics. Baltimore, MD: Richard Clay (The Causer Press) Ltd. 
Putri ,M.E., Mardiyana \& Saputro,D.R.S. (2019). The effect of application of react learning strategies on mathematics learning achievements: Empirical analysis on learning styles of junior high school students. International Journal of Educational Research Review, 4(2), $231-237$.

Stein, M. K., Grover, B. W., \& Henningsen, M. (1996). Building student capacity for mathematical thinking and reasoning: An analysis of mathematical tasks used in reform classrooms. American educational research journal, 33(2), 455-488.

Susanto, D. (2016). Eksperimentasi TTW dan TPS dengan Talking Stick Ditinjau dari Kemandirian Belajar Siswa Smp Negeri Se-Kabupaten Ngawi Tahun Ajaran 2016/2017. (Thesis UNS, Surakarta).

Wood, R., \& Ashfield, J. (2008). The use of the interactive whiteboard for creative teaching and learning in literacy and mathematics: a case study. British Journal of Educational Technology, 39(1), 84-96.

Yuniawatika. (2011). Penerapan Pembelajaran Matematika dengan Strategi REACT untuk Meningkatkan Kemampuan Koneksi dan Representasi Matematika Siswa Sekolah Dasar. E-journal Program Pascasarjana Universitas Pendidikan Ganesha Program Studi Pendidikan Dasar, 13(01), 105-119. 